\title{
The Orientation and Development of the Public Affair Management Specialty
}

\author{
Chenghui Li, Yongxian Fu, Rongxiang Chen \& Xueqi Hu \\ Department of Law and Public Affair Management \\ Changzhou University, Changzhou 213164, China \\ E-mail:501351638@qq.com
}

\begin{abstract}
Though the specialty of the public affair management has been developed for ten years, but it is still facing the actuality that the orientation and development are difficult. Only by confirming the cultivation target and the development orientation, the development of the specialty could find the development approach and method. According to the actuality of the public affair management of China and the public management education, this specialty should orientate to cultivate public management and service personnel for the establishment units, and cultivate startup and service personnel for the non-governmental organizations, and cultivate the modern citizens with public thought, public responsibility, and public ability, and cultivate the builders with modern public spirit for the local economy and the social development. Based on that, to fully perfect the course system and the teaching mode, and enhance the power of teachers, could really develop and stably enhance the specialty of the public affair management.
\end{abstract}

Keywords: Higher education, Public affair management, Specialty construction, Cultivation target, Development thought

The specialty of the public affair management has been developed for ten years in China. In these ten years, there were over three hundred colleges to found this specialty, and they all made certain exploring for the construction and development of this specialty, but at present, all of them are in the stage with crisis and mess, and more and more colleges begin to feel and notice this mess, and to find the way is their common task. The mess is mainly embodied in many aspects such as blur specialty orientation, unobvious specialty characteristics, disordered curriculum provision, quite serious employment situation (China Education Online, 2004), weak power of teachers, and feeble practice teaching. Only by confirming the orientation of the specialty, the development orientation of the specialty could be confirmed, and following aspects will be discussed for the orientation and development of this specialty.

\section{Oriented cultivation target in the public management education system: public management and service personnel for the establishment units}

The orientation of the public affair management specialty is decided by its state and function in the public management education system. The public management education of China comes from the administration management education of $1980 \mathrm{~s}$, and up to the reform of the colleges and universities undergraduate specialty catalog in 1997, the public management was first took as the first-class subject in the species of the "management", and the first-class subject of "public management" included twelve second-class subjects such as the public relation science, the public policy science, the city management, and the public management science. It is obvious that the public management and the public affair management are the paratactic second-class subjects of undergraduates under the first-class subject of "public management" (China Education Online, 2004).

In the universities of China, Tsinghua University, Beijing University and Fudan University have the college of public management, and the universities with the high-level of public management education and research development would not found the specialty of public affair management, but the specialty of public management with the education of MPA, and undertake the training task of the government officials' quality of public management for the country and provinces.

The special research and study class about the culture originality industry Development, the research and study class of public management core course, and other seven research and study classes opened by the School of Public Policy \& Management of Tsinghua University, all limit their recruitment students should have the identify requirement above the director level (individuals could be deputy director level) except for the young reserve cadres public management quality course research and study class which only required that the trained target must be the governmental young cadres (Tsinghua Government Official Training Network, 2009). Some trainings such as the social insurance agencies directors training class of the national labor and social security 
ministry and the third county-level cadres training class of Beijing have trained the county-level cadres of Beijing, and the cadres from relative national ministries and committees, and industrial cadres from various provinces and cities (School of Public Administration Renmin University of China, 2009). And other pubic management colleges in Beijing University, Fudan University, Beijing Normal University, and Nankai University all undertake the training of national or local cadres' quality of public management, and the research task about the reform, enhancement, and construction of the public management function of national governments and institutions.

At present, there are 100 colleges which have the authority to cultivate the degree of MPA. The year of 2009 is the tenth anniversary that China set up the specialty degree of MPA, and in the Recruitment Advertisement of the National MPA Degree Advisory Committee, there are 100 MPA colleges, and their cultivation target is the special talents with high level, composite and application for the governmental departments and the non-governmental public institutions, and the special talents urgently required in the public management domain. The enrollment condition is that the servicing officials who acquired the undergraduate degree with the diploma before July 31, 2006. And these colleges would mainly recruit the staffs from the governmental department and the non-governmental public management institutions. The governmental department management personnel according with the recruitment condition have to have the recommendation opinions of the provincial personnel department according to the uniform requirements of State Administration of Civil Service. For the non-governmental personnel, the qualification censor table is filled by the personnel department of their units. The matriculation proportion of non-governmental department should not exceed the $20 \%$ of the recruitment quota of the year (The Academic Degree Commission of the State Council of China Authorized 100 Universities to Cultivate MPA, 2009).

Various level CPA schools also undertake the important duty to train party and administrative cadres, state civilians, and theoretical cadres in rotation. Therefore, the main body of public management in China is the government, but the public management education cultivating governmental talents is undertook by the public management colleges of various famous universities and various level CPA schools. Though the education of MPA could cultivate high-level talents for the non-governmental institutions, but their enrollment quota could not exceed $20 \%$ of the total amount, and others are the state civilians. The actuality of the public management education in China should be important reason that the cultivation target of the public affair management specialty orientates its target as the application talents for the business units and non-governmental institutions.

In the exiting course that the government function transformation, the business unit reform, and the employment system reform of government and business unit are relatively slow, the cultivation target of the public affair management specialty is only those managers and servicers with the public management concept and new public management ability for the establishment governments and villages. In the establishment units, the consciousness of public management and service is weak, and the professionalization degree is not high, and the policy of public management and service is not complete, and there are more complex public problems which should be solved. Therefore, large numerous of professional public management talents are needed in China to engage, discover, think, and solve the public management and service problems in the establishment units. These talents include the common civilians, "village officers", and community managers, and the sources of these talents are the popular enrollment examinations for civilians, business posts, and "village officers". Though these enrollment examinations are not easier for the graduates of the public affair management specialty, but these students would more know the public management than the students of other specialties, and possess more consciousness, theories and responsibilities of the public management, so the students of the public affair management specialty should more take the enrollment examinations for civilians, business posts, and "village officers" as their employment target, and the colleges should also take them as their important direction of the specialty cultivation. Colleges should cultivate students to care about the establishment affairs with strong public consciousness and responsibility, and analyze, think, explore, and solve the problems about the public management and service by the professional spirit and ability, and really drive and promote the healthy development of the reform business of China.

Therefore, the public affair management specialty of local colleges should cultivate students' public spirit, pubic sense of responsibility, public policy analysis ability, and processing ability of public affairs. And for the public management colleges of famous universities, they should not only enhance the administration and party cadres' public spirit and modern public management level, but also train the teachers of the public management specialty for local colleges, which could offer essentially advantageous conditions for the students of the public affair management specialty to accept the professional education on higher level. 


\section{Oriented cultivation target in graduates' narrow employment environment: startup and service personnel for non-governmental organizations}

Except for cultivating talents for the business units, the cultivation target of the public affair management specialty is also to cultivate managers for the non-governmental organizations (or non-profitable organizations). But at present, the development of the non-governmental organization is not perfect in China, and the amount is small, and the operation mechanism is not complete, and they are not called as the really social organizations because of their strong dependence on the government, so the social affairs could not be really managed by the society. Whether the professional talents are deficient and the management service is not good, or the economic support could not be found though the talents and concepts are ready, and many problems still exist in the public affair management. In fact, the society still manage its affairs by itself, which could not reduce the burden of the government, but the management and service could more embody and realize the demand and will of the public, and more utilize and save the social resources. The Ministry of Education of China had added the specialty of the public affair management ten years ago in the adjustment of the undergraduate specialty catalog, and added the new specialties such as the cultural industry management, the exhibition and convention economy and management, and the public polices in 2004, which are again embodied and emphasized that the wills and decisions of the country in the government function change, the administration reform, and the government and society reform.

Therefore, the cultivation target of the public affair management specialty should not only aim at cultivating mangers and servicers for existing non-governmental organizations, but mainly cultivating the founders for non-government organizations in the current stage, and the researchers, analyzers, and establishers for the construction and management of non-governmental organizations. At present, many provincial and municipal governments all offer supports for college graduates for their business start-ups, and provide proper opportunities and better environment for the students of the public affair management specialty in the non-governmental organizations. The public affair management specialty of local colleges should more emphasize students' basic knowledge and theories for their business set-ups and management in the non-governmental organizations, and cultivate them how to finance, utilize the social resources, survey the real demand of the society in the actual national situation of China, and establish their new level and ability in this new service industry to satisfy the demand of the society.

\section{Oriented cultivation target in the inconsistent employment: modern citizens with modern public management concepts and ability}

It is the real fact that the employment approach of the students of the public affair management specialty is very narrow, so their employment in enterprise has been the necessary choice. But the mangers, constructors, and teachers of this specialty have to possess definite professional consciousness and responsibilities of the public affair management. Even the graduates in the initial stage of the public affair management specialty have to take the posts of enterprise management, the education staff should also let them take the concept, responsibility and ability of the new public management, and the development and management mode of enterprises is different with the public management, but the development and management of enterprises can not leave the national policies of the economy and management, and the social responsibility and public thought undertaken by the enterprises. In the practice of enterprise management, these graduates could feed back the economic policies and the success and failure of the public policies by the professional view of the public management, and accordingly promote and enhance the economic polices and the public polices by modern civilians' rights and obligations. And they also could pay attention to the public crisis and problems of the country and the society by the spirit of public thought, and accordingly help to dispose the public crisis and problems by the identity of enterprise or entrepreneurs, and promote the perfection of the public crisis disposal mechanism. Therefore, the cultivation and enhancement of entrepreneurs' civil consciousness will be one of important cultivation target of this specialty. The establishment of students' public theory, the cultivation of theoretical analysis ability, and the formation of the professional thinking analysis habit should be the emphases of the specialty teaching, and students should all can analyze the public problems of the society by a rational modern citizen's thinking and mind no matter which post they are, and promote the development of the social public spirit and the advancement of the social public civilization.

The cultivation of the enterprise-oriented talents of the public affair management specialty should set up the professional courses of the public beneficial enterprises, or the enterprise or industry management courses with strong industry chain, such as the water supply corporation management, the communication management, the electric power management, the bus corporation management in the public beneficial enterprises, or the tourism 
management, the originality industry management, the cartoon management, the news and press management, and the museum management in the cultural industry.

\section{Oriented cultivation target in the combination with the local economic and social development: local builders with the public spirit}

The specialty of the public affair management should cultivate the public managers and service staffs for the establishment units, and cultivate the modern citizens with modern public consciousness, theory, responsibility, and ability for the society, and the establishment property and the universal property of its cultivated object decide the localization of the specialty orientation, and the specialty should cultivate professional talents for the development of the local economy and social development. Therefore, the specialty should survey and research the city development plan, the city public business development plan, the talent demand of the city, and the talent cultivation measure and plan of the city where the school is located in detail. On the one hand, the development direction of the specialty should be confirmed in the survey and research, and on the other hand, the school should discuss the talent cultivation demand, cultivation mode, and the employment with relative city departments and units to confirm students' employment first and accordingly promote the stability and healthy development of the specialty.

\section{Development thoughts about the course system, the power of teachers, and the teaching mode}

In the orientation of the specialty, only above factors are considered, students could be seriously cultivated, and the "deep base, wide caliber, and multiple directions" of the course system could be carried out. Based on the subjects such as the politics, the economics, the management, the psychology, and the sociology, the module courses of various directions should be established respectively, such as the policy analysis, the city management, the cultural industry management, the community management, the rural public business management, and the social security, and the base of the subject is the required courses, and the module course should mainly consider the integrity of the module, with the multiple module selection. At the same time, many practical and research courses such as the public affair management case analysis, the social problem survey research, the public affair management policy analysis, and the public affair management should be provide for students to select, which could not only deepen students' professional base and develop students' professional domain, and cultivate students to grasp the habits and ability of analyzing problems by the professional view and theoretical thinking way.

In the course offering of the public affair management specialty, the teachers of this specialty are required quite higher, but the power of teacher of the public affair management specialty in local colleges is not optimistic. Teachers of this specialty should not only possess deep theoretical bases about the politics, the economics, the management, the psychology, and the sociology, but have deep theoretical level and practical ability in certain module direction, and have the teaching level and ability of teaching higher theory and practice to students. In the enhancement measure of teacher power of "introducing exteriorly and cultivating interiorly", it is very important to enhance existing teachers' level and ability, for example, some colleges appoint their teachers to attend in an advanced studies in brother colleges for the same specialty, and encourage their teachers to get a doctor's degree, and exercise their teachers in the practice base, or offer holidays to enhance their specialty, and ask famous colleges to take place the teachers training class of the public affair management specialty. In the construction and development of the specialty, the key is strong teacher power, and various colleges must make some real works to promote the development of this specialty.

With strong power of teachers, the perfect course system could be implemented in the effective teaching mode. The most effective teaching mode is the combination of theory and practice, with the instruction of theories and the analysis and operation of practice. In the instruction, students should establish the theoretical frame of the course even the subject, and fill in practice pictures and images in the theoretical frame, and the former is theory, and the latter is practice. General practice modes include practice, experiment course, graduate practice, and social practice, and these modes are necessary practice teaching part in the professional teaching. But the more feasible and convenient teaching mode combining theory with practice should be the arrangement and implementation of the practice in the course teaching. One or several teachers charge in the teaching of several courses in one module, and the theoretical instruction and practice of this courses should be designed and arranged by these teachers together, and they should bring students to study and research in the close combinations of theory and practice, such as classroom case teaching, the problem research, the spot survey, or the project participation, which could be closer with the course schedule and the theoretical content of the course, and could more embody the combination of theory and practice, and more effectively educate students than the current courses. Of course, these measures need teachers to pay sufficient energy and time to study, develop, and 
research, and need the college to largely support in many aspects such as time, charge, and system.

\section{References}

China Education Online. (2004). Undergraduate Program Catalog of National Universities and Colleges. [Online] Available: http://www.eol.cn/html/g/benkezy.shtml.

Li, Chenghui. (2009). The Development Actuality of the Public Affair Management Specialty. China Agricultural Education. No.6. p.32-33.

School of Public Administration Renmin University of China. (2009). [Online] Available: http://www.mparuc.edu.cn/peixunxiangmu/default_mpa.asp.

The Academic Degree Commission of the State Council of China Authorized 100 Universities to Cultivate MPA. (2009). [Online] Available: http://www.mpa.org.cn/zhaosheng/01.html.

Tsinghua Government Official Training Network. (2009). [Online] Available: http://www.thot.cn/tsinghua/index.jsp. 